\title{
Review
}

Journal of Innate

Immunity

\section{In Search of a Cure for Sepsis: Taming the Monster in Critical Care Medicine}

\author{
Emeka B. Okeke Jude E. Uzonna \\ Department of Immunology, Faculty of Medicine, University of Manitoba, Winnipeg, Man., Canada
}

\section{Key Words}

Cytokines · Endotoxin · Inflammation · Sepsis · Septic shock

\begin{abstract}
In spite of over half a century of research, sepsis still constitutes a major problem in health care delivery. Although advances in research have significantly increased our knowledge of the pathogenesis of sepsis and resulted in better prognosis and improved survival outcome, sepsis still remains a major challenge in modern medicine with an increase in occurrence predicted and a huge socioeconomic burden. It is generally accepted that sepsis is due to an initial hyperinflammatory response. However, numerous efforts aimed at targeting the proinflammatory cytokine network have been largely unsuccessful and the search for novel potential therapeutic targets continues. Recent studies provide compelling evidence that dysregulated anti-inflammatory responses may also contribute to sepsis mortality. Our previous studies on the role of regulatory T cells and phosphoinositide 3-kinases in sepsis highlight immunological approaches that could be explored for sepsis therapy. In this article, we review the current and emerging concepts in sepsis, highlight novel potential therapeutic targets and immunological approaches for sepsis treatment and propose a biphasic treatment approach for management of the condition.

(c) 2016 S. Karger AG, Basel
\end{abstract}

\section{Introduction}

One of the major challenges facing clinicians in modern medicine is how to effectively manage an excessive host immune response to pathogenic insults such as sepsis. This is demonstrated by the fact that despite over half a century of research efforts, sepsis and its spectrum of diseases (severe sepsis and septic shock) are still a major problem in the clinic and a leading cause of mortality, particularly for the elderly and the immunocompromised [1]. The incidence of sepsis has been on the rise over the past 4 decades, and this is predicted to continue as a result of an aging population, an increase in invasive medical procedures and the prevalence of chronic health issues. In the USA, between 1979 and 2000, the number of reported cases of sepsis increased by nearly $9 \%$ [2]. A more recent study for the period 2004-2009 reveals an approximate $13 \%$ national increase in the incidence of severe sepsis [3]. However, there is evidence that mortality from sepsis has decreased in recent years. A retrospective study of patients with severe sepsis in Australia and New Zealand revealed that between 2000 and 2012, mortality decreased from 35 to $18.4 \%$ [4]. Other studies have also reported a decrease in sepsis mortality [5-7]. It must be stated that sepsis survivorship can still be associated with significant socioeconomic burden $[8,9]$ and research efforts towards mitigating the impact of sepsis are still par-

\section{KARGER}

E-Mail karger@karger.com

www.karger.com/jin
(C) 2016 S. Karger AG, Basel

$1662-811 \mathrm{X} / 16 / 0082-0156 \$ 39.50 / 0$
Dr. Jude E. Uzonna

Department of Immunology, University of Manitoba

$750 \mathrm{McDermot}$ Avenue

Winnipeg, MB R3E 0T5 (Canada)

E-Mail jude.uzonna@umanitoba.ca 
amount. Additionally, sepsis constitutes a huge financial burden on health care delivery, with an annual cost in excess of USD 20 billion [10]. Thus, while decades of research involving several clinical and experimental studies have thrown more light on sepsis, leading to better outcomes, any increase in knowledge of the immune system provides an opportunity for the use of immunotherapy in sepsis management.

In this review, we highlight the general concepts about sepsis and discuss current knowledge of several biological and immunological processes that contribute to sepsis. We discuss the possibilities of the translation of knowledge from bench to bedside and the development of novel strategies for the treatment of sepsis.

\section{Development of Concept}

Sepsis is generally understood to indicate the presence of microbes or their toxins in the blood or tissues. This initial emphasis on the role of pathogens in the mechanisms of sepsis resulted in decades of research on antibiotic therapies for the clinical management of the disease. Increased understanding of the nature of immune responses during infection led to a change in paradigm and the prevailing view that the host immune response plays a major role in the progression of sepsis [11]. In 1991, the American College of Chest Physicians (ACCP) developed a set of recommendations and guidelines for the diagnosis and treatment of sepsis, and laid out strict definitions of terms associated with sepsis syndrome in order to facilitate easy diagnosis and treatment and aid in the interpretation of the results of basic research and clinical trials [12]. Sepsis was subsequently defined as a systemic response to an insult. If this response occurred in the absence of infection, the condition was described as systemic inflammatory response syndrome (SIRS). Over the years, as the knowledge of the pathophysiology of sepsis increased and also based on several clinical observations, these definitions of sepsis and its spectrum of diseases have been found to be unspecific and in need of modification. In 2001, the International Sepsis Definition Conference (ISDC) was convened, with the intention of changing the definition of sepsis and basing it on biomarkers. However, participants at the conference agreed that the use of biomarkers for sepsis diagnosis is premature, and opted to let the definition of sepsis by ACCP stand. However, for the ease of sepsis diagnosis, they provided a staging system for sepsis called PIRO that stratified patients on the basis of their predisposing conditions, the nature

Management of Sepsis in Critical Care Medicine and extent of the insult (infection, in the case of sepsis), the nature and magnitude of the host response and the degree of accompanying organ dysfunction [13].

A major problem in the diagnosis of sepsis is the lack of an adequate biomarker. The current criteria for the diagnosis of sepsis greatly lack specificity. For instance, the parameters, white blood cell (WBC) count and body temperature, can be misleading as WBC count may be higher or lower than the recommended value and the high body temperature may not be due to infection. This makes the requirement for a highly reliable biomarker for sepsis diagnosis essential.

An ideal biomarker should be able to accurately diagnose patients with sepsis. It should also be able to predict outcome, serve as a staging marker for the evaluation of disease severity, be relatively easy to measure, predict/ identify organ dysfunction, be economically feasible and possibly identify infecting organism. However, the heterogeneous and dynamic nature of sepsis has made the discovery of an adequate biomarker with a high degree of accuracy and sensitivity inherently difficult. Nearly 200 sepsis biomarkers have been evaluated in different studies with limited success [14]. This is not surprising since scientists are faced with the onerous task of finding a specific marker for sepsis, which usually has an unspecific phenotype relative to other inflammatory conditions.

The acute-phase protein, C-reactive protein (CRP), is a widely used marker for systemic inflammation and tissue injury, and has been investigated as a biomarker for sepsis. It has been shown to be a good predictor for sepsis with sensitivity and specificity values of 98.5 and $75 \%$, respectively [15]. It has also been shown to be able to distinguish between true bacteremia and contaminated blood cultures [16]. Additionally, CRP is useful in the evaluation of the response of patients to sepsis treatment [17] and is a good predictor of sepsis mortality [18]. Although CRP alone is not sufficient for sepsis diagnosis, it is a better indicator of sepsis than WBC count and is a welcome addition to the treatment of sepsis patients.

Recently, studies have shown that procalcitonin (PCT) is a better diagnostic marker for sepsis than CRP [19]. PCT is a precursor peptide of calcitonin composed of 116 amino acids and is produced by the $\mathrm{C}$ cells of the thyroid gland. Proteolytic cleavage of PCT gives rise to calcitonin [20]. However, unlike calcitonin, PCT has a long half-life, which makes it a more desirable biomarker. Hohn et al. [21] showed that PCT is a good diagnostic marker for sepsis and that adherence to PCT protocol reduces the duration of antibiotic therapy. Other studies have shown that PCT is a good predictor of sepsis outcome [22] and 
can be successfully used to rule out sepsis in the clinic [23]. Conversely, Tang et al. [24], in their meta-analysis literature review, observed a low diagnostic performance for PCT and showed that PCT levels could not accurately differentiate sepsis from systemic inflammatory response syndrome. Nevertheless, the results obtained from studies on the use of PCT as a potential biomarker for sepsis are encouraging.

Bioinformatics and the technology of 'omics' have great potential to identify a reliable biomarker for sepsis. Mickiewicz et al. [25] used nuclear magnetic resonance spectroscopy-based metabolomics for the diagnosis of pediatric septic shock. Although their data are comparable to PCT measurement for sepsis diagnosis, they showed that their metabolomics approach was a better predictor of disease outcome. Kwon et al. [26] used proteomics to analyze the secretome of endothelial cells following LPS stimulation and subsequently identified moesin and 19 new sepsis biomarker candidates. Nakada et al. [27] used bioinformatics approach to identify a single nucleotide polymorphism on the SVEP1 gene that is associated with increased sepsis mortality. More work is needed to identify a reliable biomarker for the diagnosis of sepsis. One that will be able to identify the different stages of sepsis (severe sepsis and septic shock) would be highly desirable. It may be that the use of multiple parameters instead of a single biomarker will lead to improved accuracy and reliability, as shown by the work of Gibot et al. [28]. In any case, biomarkers able to accurately identify patients with sepsis are critical for the reduction of sepsis mortality.

\section{Pathogenesis of Sepsis}

The normal immune response to pathogenic insult leads to the activation of host defense mechanisms to counter the pathogen and prevent colonization of the host by the microbe. This involves cellular activation, vasodilation, leukocyte recruitment and increased endothelial permeability $[29,30]$. Simultaneously, there are feedback mechanisms that are in place to prevent overactivation of the host immune responses and ensure a return to homeostasis. Dysfunction in immune regulation can lead to an overwhelmingly high and mismatched immune response, resulting in a sustained proinflammatory state, the end result of which is tissue injury and organ dysfunction [31]. Immune dysfunction can also lead to a sustained anti-inflammatory state of the immune system resulting in anergy and immunosuppression [32].
Microbes such as bacteria, fungi, viruses and parasites have distinct molecular components that trigger immune responses in the host. These molecular structures are commonly referred to as pathogen-associated molecular patterns (PAMPs) or microbial-associated molecular patterns (MAMPs) since they also occur in nonpathogenic microbes [33]. The detection of PAMPs by germ-lineencoded pattern recognition receptors (PRRs) triggers the initiation of a cascade of host immune responses. Four classes of PRR have been described: (1) Toll-like receptors (TLRs), (2) nucleotide-oligomerization domain leucine-rich repeat proteins (NOD-LRR), (3) cytoplasmic caspase activation and recruiting domain helicases such as retinoic acid-inducible gene I-like helicases and (4) C-type lectin receptors expressed on dendritic and myeloid cells $[34,35]$. The most studied PRRs are the TLRs, which are expressed by a variety of innate immune cells including endothelial cells, macrophages, dendritic cells and monocytes. In the case of Gram-negative bacterial infection, TLR4 recognizes lipopolysaccharide (LPS), an endotoxin found on the cell wall of Gram-negative bacteria. The recognition of LPS through TLR4 involves the interaction of several proteins including LPS-binding protein (LBP), CD14 and MD-2 [36]. MD-2 is noncovalently associated with TLR4, forming the TLR4/MD-2 receptor complex. The ligation of TLR4 by LPS leads to the activation of several intracellular signal transduction pathways involving hemodynamic changes, the recruitment of leukocytes such as neutrophils and macrophages to the site of infection and the systemic release of cytokine mediators such as tumor necrosis factor (TNF), interleukin (IL)-1, IL-6 and IL-8 [37, 38]. TNF and IL-1 induce vasodilation, facilitate the release of secondary mediators such as nitric oxide (NO), platelet activation factor (PAF), prostaglandins and leukotrienes as well as the activation of the complement system $[39,40]$. When there is an overwhelming immune response, these inflammatory mediators cause endothelial damage and capillary leakage. Cytokines also activate the coagulation pathway, leading to capillary microthrombi, tissue hypoperfusion and end-organ ischemia [41]. The sustained and continuous release of these proinflammatory mediators results in multiple organ dysfunction syndrome (MODS), as seen in severe sepsis, and eventually results in hypotension that leads to septic shock.

In addition to the proinflammatory state initiated by the immune response to infection, anti-inflammatory mediators such as IL-4, IL-10 and transforming growth factor $\beta$ (TGF- $\beta$ ) are also released to ensure that the immune system returns to homeostasis. Initially, the roles of 
these anti-inflammatory mediators in sepsis were neglected. Accumulating evidence indicates that septicshock patients exhibit signs of immunosuppression [32, 42]. This is because homeostasis can only be achieved if anti-inflammatory mediators are released in optimal amounts. If these mediators are released in excess, they will dampen the host immune responses, leading to an inability to fight the infection. This phenomenon has been termed compensatory anti-inflammatory response syndrome (CARS) [32]. IL-4 promotes Th2 cell responses, inhibits Th1 cell activity and suppresses macrophage activity [43]. IL-10 is a potent anti-inflammatory cytokine and inhibits the cytokine activity of several immune cells $[43,44]$. TGF- $\beta$ suppresses $\mathrm{T}$ and $\mathrm{B}$ cell proliferation and differentiation $[45,46]$ and limits the production of TNF and IL-1-induced NO production [47]. The end result of a high anti-inflammatory response is a dampened immune state, which will lead to the inability to clear the infection and increase susceptibility to nosocomial or secondary infections.

Sepsis is a systemic and dynamic syndrome, and knowledge about the mechanisms of disease progression is increasing over the years. In addition, the roles that cytokines and inflammatory pathways play in sepsis pathogenesis are gradually being elucidated $[48,49]$. The application of bioinformatics and computerized mathematical models has also contributed to greater knowledge of the pathogenesis of sepsis $[27,50]$. It is hoped that these novel discoveries will tremendously improve the outcome of the critically ill patient.

Current research efforts are aimed at targeting important steps in the host immune response to infection rather than the pathogen itself. Nevertheless, research into sepsis treatment has been barely successful, with numerous clinical trials in sepsis having failed and the task of developing adequate pharmacological intervention in sepsis proving to be Herculean. However, with the increase in knowledge and advances in technology, it is hoped that more novel therapeutic interventions will lead to effective and efficient treatment of sepsis syndrome. Below, we discuss some potential therapeutic targets in sepsis.

\section{Targeting Inflammation}

One of the earliest anti-inflammatory therapies against sepsis was the use of corticosteroids [51]. However, after more than half a century of corticosteroid administration, its benefits to septic-shock patients have been re-

Management of Sepsis in Critical Care Medicine peatedly questioned, with some researchers arguing against its use [52]. The use of corticosteroids in sepsis treatment is partly justified by the evidence of adrenal insufficiency in sepsis patients [53], and numerous reports on experimental animal models of sepsis show that it is indeed beneficial $[54,55]$. In a randomized double-blind multi-center clinical trial, Annane et al. [56] showed that low-dose corticosteroids significantly reduced the risk of death in all patients with septic shock, especially those with relative adrenal insufficiency. This finding led to a much larger trial, the CORTICUS (Corticosteroid Therapy of Septic Shock) trial. However, this trial failed to demonstrate any significant survival benefit of low-dose hydrocortisone therapy in patients with septic shock regardless of whether they have relative adrenal insufficiency [57]. The failure of the trial further strengthened the pessimism associated with the administration of corticosteroids to patients with sepsis. Recently, Boonen et al. [58] showed that patients in the ICU have greater cortisol production, reduced cortisol metabolism and suppressed corticotropin response compared to control subjects. Their finding is significant because it shows that the daily administration of $200 \mathrm{mg}$ of hydrocortisone as used by Annane et al. [56] and in the CORTICUS trial is 3 times too high and that critically ill patients have normal production of cortisol. Hence, a low cortisol response to corticotropin stimulation does not necessarily mean adrenal insufficiency. The potential benefit of corticosteroid administration to patients with sepsis is still of significant interest. The ADRENAL (Adjunctive Corticosteroid Treatment in Critically Ill Patients with Septic Shock) clinical trial is currently underway in Australia and New Zealand (clinicaltrials.gov identifier NCT01448109). A larger study like the ADRENAL trial may end up showing a benefit of corticosteroid administration to at least a select group of patients with sepsis.

The understanding of the immunopathogenesis of sepsis led to the development of more anti-inflammatory therapies targeting specific proteins known to initiate and/or participate in the induction of inflammatory response. LPS, the major component of the cell wall of Gram-negative bacteria, is one of the most potent activators of the immune system. The recognition of LPS through its interaction with the TLR4/MD2 complex triggers the initial proinflammatory immune state in sepsis, and the inhibition of LPS-induced proinflammatory cytokine production is protective in experimental sepsis $[59,60]$. Studies also show that an increased level of endotoxin correlates with the severity of illness in sepsis [61]. Hence, inhibition of LPS signaling is a veritable ap- 
proach to sepsis therapy. Indeed, blocking TLR4, the receptor for LPS, was found to be protective in animal models of sepsis $[62,63]$. The TLR4 small-molecule inhibitor, eritoran, was found to be protective in experimental human endotoxemia $[64,65]$, even though a recently concluded randomized clinical trial found it to have no impact on sepsis mortality [66].

An alternative approach to inhibition of endotoxin signaling is to directly target the endotoxin itself. The antibiotic, polymyxin B (PMXB), binds to endotoxin and neutralizes its activity [67]. There is significant interest in the use of PMXB for sepsis treatment. However, intravenous infusion of PMXB in humans leads to neurotoxicity and nephrotoxicity, thereby limiting its use. To circumvent this problem, a novel approach was developed whereby PMXB was adsorbed to polystyrene fibers to create an extracorporeal direct hemoperfusion device toraymyxin [68]. Toraymyxin is currently available for the treatment of sepsis in Japan and Europe, and results have been encouraging. A review of the literature shows that direct hemoperfusion with PMXB fibers leads to an overall improvement in the clinical parameters of sepsis patients including mortality [69]. A nonblinded randomized clinical trial of PMXB hemoperfusion (EUPHAS) showed improved hemodynamics, decreased organ dysfunction and reduced 28-day mortality in patients with severe sepsis and/or septic shock from intra-abdominal Gram-negative bacterial infections [70]. A much larger, blinded trial of PMXB hemoperfusion in septic-shock patients (EUPHRATES) is currently ongoing in North America [71]. Since Gram-negative bacterial infections are the major cause of sepsis [72], endotoxin therapy holds promise for an improvement in outcome for patients with sepsis.

Recently, there is interest in the manipulation of the immune response to enable the clearance of pathogenic lipids like LPS by the immune system. Upon interaction with transfer proteins like LPS-binding protein (LBP), LPS is first sequestered in high-density lipoproteins (HDL) and then transferred to low-density lipoproteins (LDL) for clearance by hepatic cells $[73,74]$. The interaction of LPS with lipoproteins is significant because this leads to LPS inactivation and the subsequent suppression of the inflammatory response [75]. Therefore, increasing LPS sequestration and inactivation by lipoproteins is a reasonable approach for the treatment of Gram-negative infections. The proprotein convertase, subtilisin/kexin type 9 (PCSK9), is a regulatory molecule that inhibits the clearance of endogenous lipids from the blood. PCSK9 binds to LDL receptor (LDLR) on hepatic cells, thereby promoting its internalization and lysosomal degradation as well as preventing its recycling to the cell surface [76]. Hence, PCSK9 activity decreases LDL clearance and increases the levels of LDL cholesterol in the plasma. In line with this, gain-of-function of the PCSK9 gene is associated with an increased risk of cardiovascular disease and myocardial infarction [77]. These observations led to the development of PCSK9 inhibitors, which increase LDL clearance and reduce the risk of cardiovascular disease [78]. Since the processes of elimination of endogenous lipids and pathogen lipids are similar, it is possible that inhibition of PCSK9 activity will be beneficial to patients with sepsis. Indeed, Walley et al. [79] showed that mice lacking PCSK9 activity showed a diminished inflammatory response to LPS and increased LPS clearance. They also showed that in patients with septic shock, loss-offunction variants of the PCSK9 gene were associated with decreased cardiovascular dysfunction and mortality. More studies are needed to ascertain the benefit of inhibition of PCSK9 activity in patients with sepsis. It is worthy of note that the inhibition of PCSK9 activity holds promise, not only for patients with Gram-negative bacterial infections, but also for patients with Gram-positive bacterial infections and fungal infections.

The possibility of blocking cytokine activity was initially welcomed with excitement for its potential in sepsis therapy, but the excitement has gradually waned. For example, TNF inhibitors have been effective as therapeutic anti-inflammatory agents and several TNF inhibitors have been approved by the US FDA for the treatment of rheumatoid arthritis, psoriatic arthritis and Crohn's disease, resulting in market sales of over USD 13 billion dollars in 2008 [80]. However, clinical trials of anti-TNF therapy in sepsis have not been successful $[81,82]$. In addition to anti-TNF therapy, several research efforts have been dedicated to investigating the potential of therapies targeting proinflammatory cytokines in sepsis. Recently, Weber et al. [49] reported on the role of IL-3 in sepsis and that IL-3 deficiency protects mice from sepsis. This adds to reports that blockade of high-mobility group box 1 (HMGB1) [83], IL-17 [84], IL-1 [85] and many other cytokines was protective in experimental models of sepsis. However, more than 40 clinical trials on anti-inflammatory therapeutic agents have failed, implying a significant disconnect between experimental and clinical sepsis [86].

Paradoxically, there is emerging interest in the use of the proinflammatory approach for sepsis treatment. Since many studies have shown that patients with sepsis exhibit signs of immune suppression, immune activation is therefore a veritable approach in sepsis therapy. The con- 
cept of endotoxin tolerance, which shows that pretreatment with endotoxin leads to reduced mortality upon secondary lethal challenge, has been known since the 1960s [87]. The response of the immune cells of sepsis patients suggests that endotoxin tolerance occurs during sepsis. For example, studies have shown that monocytes from patients with sepsis are hyporesponsive and have a reduced expression of HLA-DR, which leads to a diminished antigen presentation ability $[88,89]$. Indeed, there is evidence of monocyte 'reprogramming' by endotoxin from a proinflammatory to an anti-inflammatory phenotype $[90,91]$. The concept of $\mathrm{T}$ cell exhaustion, whereby T cells exhibit diminished effector functions upon stimulation, has also been reported in sepsis [92, 93]. Additionally, studies have shown that apoptosis of immune cells is a hallmark of sepsis and contributes to mortality [94-96]. Further evidence of immune suppression in sepsis is demonstrated by the reactivation of latent viruses in patients with prolonged sepsis, a phenotype characteristic of a weakened immune state [97]. These observations suggest that therapies aimed at boosting the immune response may be beneficial for sepsis patients. Indeed, blocking apoptosis was shown to improve survival in experimental sepsis $[96,98]$. Other approaches to improve the immune response of patients with sepsis are discussed below.

\section{Immune Activation}

There is compelling evidence showing that immune activation may be beneficial to sepsis patients. Indeed, studies have shown that it improves recovery from sepsis. For example, the cytokine IL-7, known to improve T cell expansion and proliferation and decrease lymphocyte apoptosis $[99,100]$, has been shown to be effective in rejuvenating the immune system. IL-7 signals via the IL-7 receptor (IL-7R) which consists of a heterodimer of IL$7 \mathrm{Ra}$ (CD127) and the common cytokine receptor $\gamma$ chain ( $\gamma c ; C D 132)$ [99]. T cells express IL-7Ra and defects in IL-7R $\alpha$ abolish T cell development [101]. Recombinant human IL-7 (rhIL-7) is currently being investigated in the clinic as a therapy for cancer and HIV with promising results [100]. IL-7 has also been shown to have beneficial effects in human and animal model of sepsis. Unsinger et al. [102] showed that IL-7 therapy improved sepsis survival by decreasing lymphocyte apoptosis and improving lymphocyte effector functions such as proliferation and IFN- $\gamma$ cytokine production. Venet et al. [103] showed that ex vivo stimulation with rhIL-7 also improved lym-

Management of Sepsis in Critical Care Medicine phocyte proliferation and IFN- $\gamma$ cytokine production and increased expression of the antiapoptotic protein $\mathrm{B}$ cell lymphoma 2 (Bcl-2). Other studies have reported the benefit of IL-7 therapy in sepsis $[104,105]$.

Granulocyte-macrophage colony stimulating factor (GM-CSF) is another cytokine that has been shown to hold promise for sepsis immunotherapy. It promotes the differentiation of granulocytes and monocytes from stem cells and thereby expands these populations of immune cells critical for fighting infection. In line with this, GMCSF therapy was able to restore macrophage activity after cecal ligation and puncture (CLP) in mice [106]. In fact, a phase II clinical trial of GM-CSF was found to decrease the length of supportive care and length of stay in the ICU for sepsis patients [107].

Another strategy to boost the immune response is the blockade of immune checkpoints. This involves blocking the activity of molecules that are known to downregulate the immune response. For example, antibodies against the inhibitory molecule, cytotoxic T-lymphocyte-associated antigen 4 (CTLA-4), is currently being used in cancer therapy [108]. Recently, there is emerging interest in the inhibitory molecule programmed cell death protein 1 (PD-1) and its ligand (PD-L1). PD-1 is expressed on activated T cells while PD-L1 is expressed on antigen-presenting cells. Blockade of PD-1/PD-L1 signaling has been shown to boost immune responses and increase the survival of cancer patients [109]. It is anticipated that blockade of immune checkpoints in sepsis would be beneficial because, similar to cancer, patients with sepsis exhibit signs of suppressed immune function [110]. Indeed, inhibition of PD-1 signaling has been attempted in experimental sepsis with encouraging results. Brahmamdam et al. [111] showed that inhibition of PD-1 signaling improves survival in murine CLP. Similarly, Chang et al. [112] showed that blockade of either PD-1 or CTLA-4 improves survival in fungal sepsis. Clinical studies of the effect of PD-1 or CTLA-4 blockade will be useful to ascertain the benefit of this therapy for sepsis patients.

\section{Immune Activation versus Immune Suppression}

Based on these observations, one may ask, which approach to sepsis treatment is most appropriate? Should the approach be to activate the immune system or to suppress it? We contend that either approach can be correct depending on the degree of disease progression. In this regard, an accurate biomarker and staging criteria for pa- 
Fig. 1. Different phases of sepsis require different therapeutic approaches: phase I is identified as the cytokine secretion phase and phase II is the immune paralysis phase. Suggested therapies are outlined in each given phase.

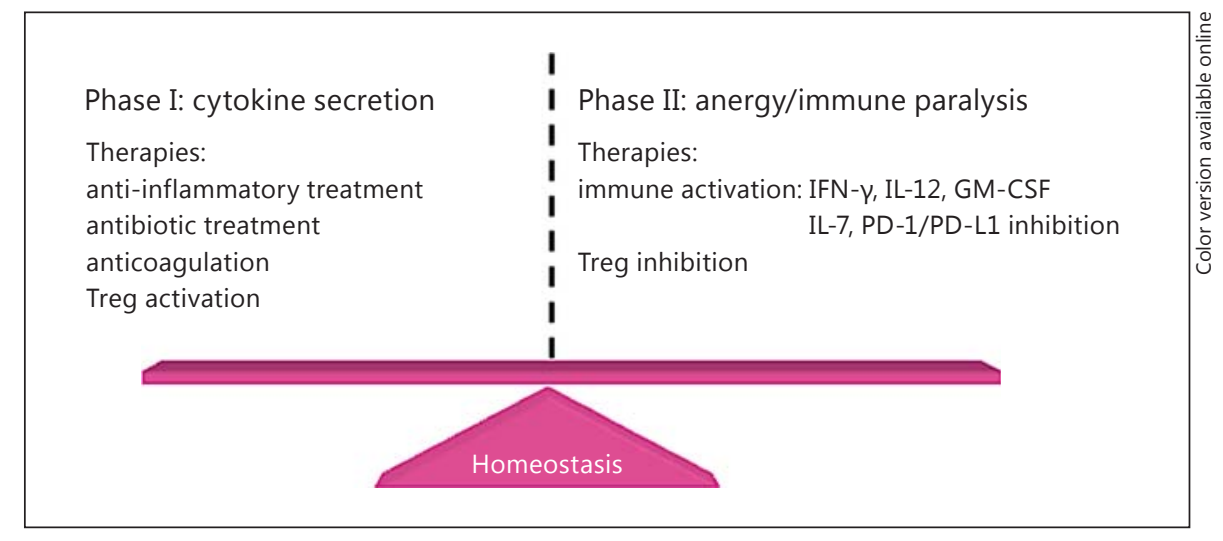

tients with sepsis are essential. Patients in the early stage of sepsis may have their immune system tilted towards a proinflammatory state and will therefore require therapies aimed at suppressing the immune response. On the contrary, patients in the later stages of sepsis may have a suppressed immune state and will require their immune system to be activated. Since sepsis is a heterogeneous and dynamic syndrome, it is expected that treatment should be case-specific. The failure of several clinical trials may be partly due to their use of similar criteria for the assessment of individuals with divergent presentations.

Additionally, blocking one cytokine may not be an effective clinical approach for sepsis. This is because there are several cytokines with redundant functions and activities that contribute to a network of inflammatory signals involved in the pathogenesis of sepsis. As a result, eliminating the effects of one cytokine hardly abolishes the effects of numerous others involved in the process. In this regard, modulating biological pathways like the phosphoinositide 3-kinase (PI3K) pathway or directly utilizing a subpopulation of immune cells like regulatory $\mathrm{T}$ cells (Tregs) may be more beneficial in sepsis therapy. These are discussed in greater detail below.

We propose a 2-phase treatment of sepsis, i.e. the suppression-activation approach (fig. 1). The first phase involves the reduction of the initial hyperinflammatory response by targeting the essential elements involved in this process. Indeed, success may be obtained in this phase and recovery achieved. If that is not the case and the patient shows considerable progress to severe sepsis, antiinflammatory therapy should be discontinued and factors involved in immune suppression should be targeted, with the aim of activating the host immune responses. The use of biomarkers for the identification of patients in a particular phase will be highly beneficial.

\section{The Role of Regulatory T Cells}

CD4+ T cells that constitutively express CD25 and the transcription factor Foxp3 have been described as natural Tregs. These cells are generated in the thymus through the altered negative selection of self-peptides and play a major role in the maintenance of peripheral tolerance to self- and foreign antigens $[113,114]$. The suppressive nature of Tregs has been described both in vivo and in vitro; they play a critical role in regulating the pathogenesis of several autoimmune diseases [115]. An increase in the frequency of Tregs has been reported in clinical and in animal models of sepsis [116, 117]. However, whether Tregs play a protective role in sepsis by downregulating inflammation or whether they contribute to immune dysfunction by suppressing effector T cells is unclear [118]. Scumpia et al. [119] reported that inhibition of Treg activity either by antibody depletion or genetic ablation has no effect on sepsis-associated mortality. Carrigan et al. [120] reported that antibody depletion of Tregs had no effect on acute lung infection caused by Pseudomonas aeruginosa. Additionally, several studies have demonstrated that Tregs contribute to immune suppression in sepsis and that the inhibition of Treg activity may be beneficial in sepsis [117, 121, 122]. Conversely, Heuer et al. [123] reported that the adoptive transfer of in vitro stimulated Tregs increased bacterial clearance and improved survival in a murine CLP model of sepsis, thereby demonstrating the beneficial role of Tregs in a clinically relevant model of sepsis. Cambos et al. [124] showed that Tregs help to control excessive inflammation in lethal Plasmodium chabaudi adami infection, in which mortality is associated with a systemic inflammatory response. In line with the observation of Heuer et al. [123], our laboratory recently showed that the immunological or genetic inhi- 


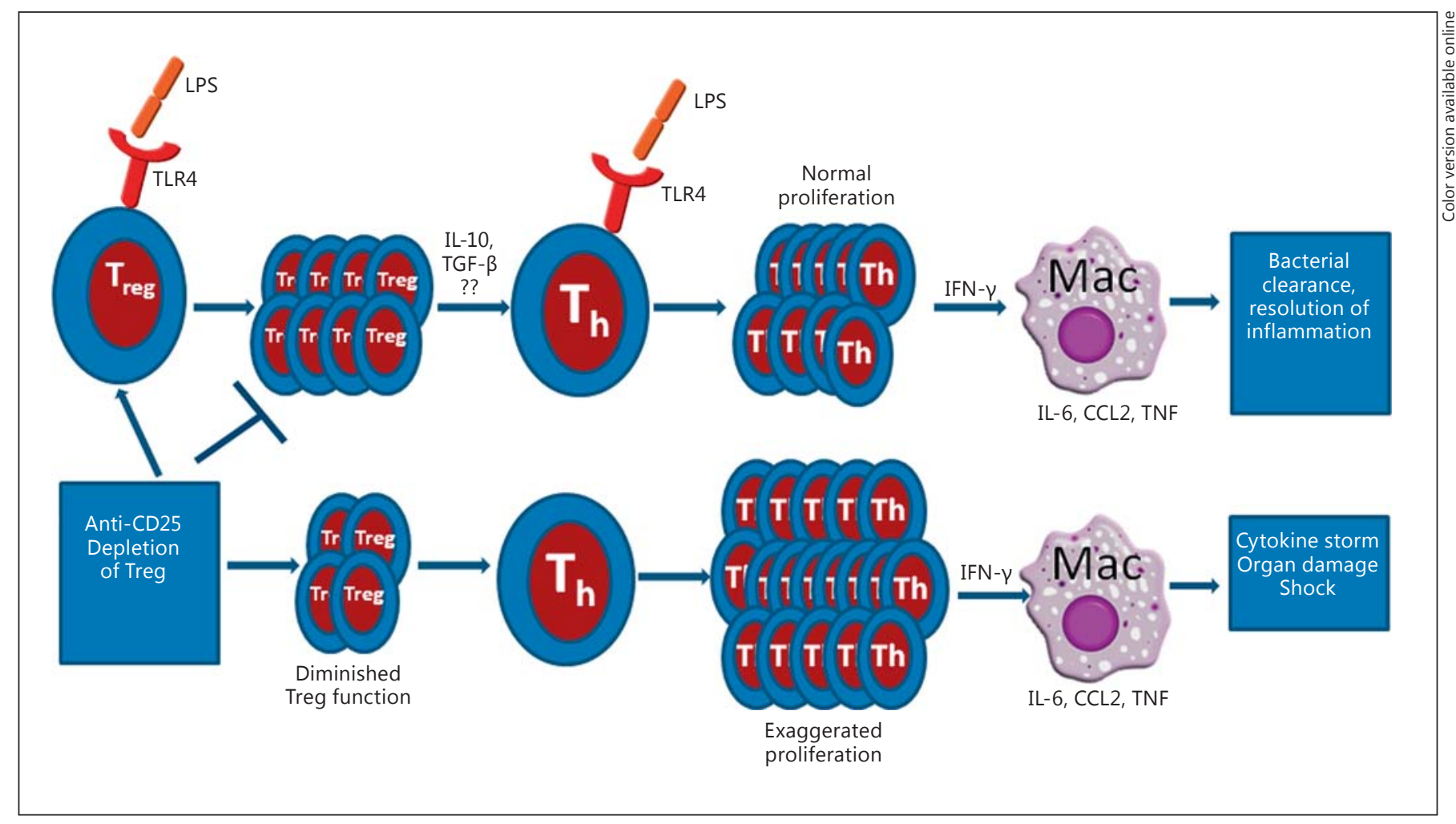

Fig. 2. Regulation of effector CD4+ T (Th) cell response to LPS by Tregs. Both Tregs and Th cells express TLR4 and respond to LPS, leading to their activation and proliferation. In the presence of adequate Treg function, the proliferative capacity of Th cells is controlled and their ability to activate macrophages is properly regu- lated, leading to the resolution of infection. However, reduction in Treg function (due to either Treg depletion or genetic ablation) allows excessive and unrestrained activation and proliferation of Th cells and the subsequent hyperactivation of macrophages, leading to cytokine storm, organ failure and death. bition of Treg function, using an anti-CD25 monoclonal antibody treatment or mice lacking functional Tregs (CD25 KO mice), respectively, was detrimental in a sepsis model of bacterial infection or LPS-induced acute inflammatory response [125]. This was accompanied by exaggerated production of proinflammatory cytokines including IL-1 $\beta$, IL-6, IL-12, TNF and CCL2. Strikingly, adoptive transfer of Tregs into CD25 KO mice before LPS challenge rescues mice from death [125]. Furthermore, we demonstrated the mechanism by which Tregs regulate inflammation during sepsis. We showed that effector CD4+ T cells respond to LPS and that Tregs regulate the magnitude of response of effector CD4+ T cells to LPS [126]. In the absence of Tregs, effector CD4+ T cells become hyperresponsive to LPS and robustly activate macrophages, leading to the excessive production of proinflammatory cytokines, SIRS and death [126]. Collectively, our results indicate that, in the absence of adequate Treg function, effector CD4+ T cells exhibit increased cellular activity in response to LPS. This increased effector T cell activity leads to the exuberant activation of other immune cells such as macrophages, resulting in excessive inflammatory response, organ damage and mortality [126] (fig. 2).

One important implication of our work is the potential for using Tregs in the clinical management of sepsis. We showed that adoptive transfer of Tregs rescued mice from LPS-induced mortality [125]. Treg therapy has also been established in animal models of several immune-mediated inflammatory diseases like type 1 diabetes [127] and graft-versus-host disease (GVHD) [128]. Recently, Treg therapy has found its application in the clinic. Di Ianni et al. [129] performed the first human Treg infusion therapy for the prevention of GVHD in patients with HLA-unmatched donors in bone marrow transplantation. Similar work has also been reported by Brunstein et al. [130]. The use of Treg therapy for clinical sepsis is foreseeable in the future, particularly in the early stages of sepsis when ex- 
Table 1. Novel potential therapeutic agents for sepsis

\begin{tabular}{|c|c|c|}
\hline Effector & Target & Reference \\
\hline Macrophage migration inhibitory factor (MIF) antagonist & MIF & [147] \\
\hline Complement factor C5a antagonist & $\mathrm{C} 5 \mathrm{a}$ & [148] \\
\hline Sphingosine kinase 1 antagonist (SphK1) & SphK1 & [149] \\
\hline [3-(5'-hydroxymethyl-2'-furyl)-1-benzylindazole] & guanylyl cyclase & [150] \\
\hline Statins & pleiotropic & [151] \\
\hline Farnesyltransferase inhibitor & farnesyltransferase & {$[152]$} \\
\hline Heparin & apolipoprotein E & [153] \\
\hline Transient receptor protein melastatin 4 (TRPM4) antagonist & TRPM4 & [154] \\
\hline $\begin{array}{l}\text { (S)-1-(a-naphthylmethyl)-6,7-dihydroxy-1,2,3,4- } \\
\text { tetrahydroisoquinoline }\end{array}$ & pleiotropic & [155] \\
\hline CD24-SiglecG interaction inhibitor & CD24-SiglecG interaction & {$[156]$} \\
\hline Gelsolin & inflammatory signaling & [157] \\
\hline C1-esterase inhibitor & pleiotropic & {$[158]$} \\
\hline Sildenafil & $\begin{array}{l}\text { cyclic guanosine monophosphate-specific phospho- } \\
\text { diesterase type } 5\end{array}$ & {$[159]$} \\
\hline Tie2 agonist & endothelium tie 2 & {$[160]$} \\
\hline Protocatechuic aldehyde & inflammatory signaling & {$[161]$} \\
\hline Endotoxin absorber & endotoxin & {$[162]$} \\
\hline PD-1/PD-L1 inhibitor & PD-1/PD-L1 interaction & [111] \\
\hline PCSK9 inhibitor & PCSK9 & [79] \\
\hline
\end{tabular}

cessive inflammation is a major concern (fig. 1). A reasonable approach will be to screen for markers associated with immune suppression, e.g. monocyte HLA-DR expression, and thereby identify patients who may benefit from Treg therapy. More work is needed to establish the role of Tregs in the pathogenesis of sepsis and septic shock and the possible therapeutic approaches involving Tregs in sepsis.

\section{The Role of PI3Ks}

PI3Ks are family of lipid kinases that have the unique ability to phosphorylate the $3^{\prime}$-hydroxyl group of phosphatidylinositol and phosphoinositides, leading to the activation of signaling pathways associated with numerous cell functions such as growth, differentiation, proliferation, motility, metabolism, trafficking and survival [131, 132]. PI3Ks are classified into 3 groups (classes I-III) based on their substrate specificity and sequence homology. Class I PI3Ks are the most studied and are further subdivided into class IA and class IB. Class IA PI3K is a heterodimer that consists of a 85 regulatory subunit and 1 of the 3 p110 catalytic subunits (p110a, p110 $\beta$ and $\mathrm{p} 110 \delta$ ). The first 2 isoforms (p110a and p110 $\beta$ ) are expressed in all cells, while p110 $\delta$ is primarily expressed in leukocytes. Class IB PI3K is also a heterodimer that consists of a p101 regulatory subunit and p110 catalytic subunit $(\mathrm{p} 110 \gamma)[132,133]$. The PI3K signaling pathway has been implicated in inflammation and sepsis. Studies have shown that PI3K signaling plays a protective role in sepsis and that inhibition of PI3K signaling increases mortality in experimental sepsis [134-136]. However, it must be stressed that most of these studies used pharmacological agents that globally inhibit PI3K signaling. Studies using specific inhibitors of PI3K isoforms will be more beneficial in providing insight into the role of the individual isoforms of PI3K in the pathogenesis of sepsis. Ong et al. [137] showed that genetic deletion of the p110 $\gamma$ isoform of PI3K leads to increased infiltration of polymorphonuclear leukocytes in the lungs during sepsis, which contributes to sepsis-induced organ damage. Conversely, Martin et al. [138] showed that inhibition of p110 $\gamma$ activity improves survival in sepsis. Unpublished data from our lab show that inhibition of p $110 \delta$ activity leads to increased neutrophil activity and enhances mortality in sepsis. Interestingly, mice with an inactivating knock-in mutation in the p110 $\delta$ gene ( $110 \delta \mathrm{KI}$ ) have impaired function and dramatically fewer numbers of Tregs [139]. Since Tregs have been shown to be beneficial in sepsis [123-126], it is conceivable that the enhanced susceptibility of p $110 \delta \mathrm{KI}$ mice might be related to this impaired function and re- 
duced Treg numbers. Indeed, we found that adoptive transfer of wild-type Tregs into p110 $\delta \mathrm{KI}$ mice rescued them from lethal LPS challenge. Since PI3K signaling is involved in several cellular processes that are important in the pathogenesis of sepsis, modulation of this pathway may be a potential therapeutic strategy for sepsis.

\section{Conclusion}

Several novel potential targets for sepsis treatment have been reported in the literature and intensive research efforts signal hope for sepsis treatment in the future (table 1). It is expected that these novel discoveries will be effectively translated for the treatment of critically ill patients. Since sepsis is a dynamic and heterogeneous condition, a single therapeutic target may not be feasible. A combinatorial approach, in which several aspects of the disease are targeted, might be of more benefit to patients. More importantly, as our knowledge of the pathogenesis of sepsis increases, approaches toward successful treatment should be modified. Several therapies for sepsis focused on the control of the initial hyperinflammatory response and resulted in limited success. The significance of the anti-inflammatory response that follows the initial inflammatory response in sepsis was hitherto ignored, but recent studies have shown that this could lead to a depressed immune state and contribute significantly to mortality in sepsis [42]. In addition, the heterogeneity of sepsis patients has greatly contributed to the difficulty in translating research from bench to bedside [140, 141].

Sepsis has been described as the graveyard for pharmaceutical companies, as a result of the failure of several clinical trials that were prompted by the encouraging results in animal models. One of the reasons for this is that animal models of sepsis do not adequately mimic the dis- ease in humans $[142,143]$. The development of animal models that will effectively mimic the disease in humans is crucial for the success of future clinical trials and for the treatment of sepsis.

A slight modification of the current treatment regimen may also be a reasonable approach to get the desired outcome. For example, Barkhausen et al. [144] recently showed that selective inhibition of IL- 6 was more beneficial than its complete blockade. Immunotherapy is a rapidly emerging concept in sepsis treatment. Again, an adequate staging system is essential for the characterization of the critically ill. In a hyperinflammatory immune state, immune cells like Tregs are essential to prevent endothelial damage and aggressive immune response [123-126]. In an immunosuppressive state, macrophage activation and therapies targeting suppressor mechanisms, like PD1 , may be desirable [112].

As our knowledge and understanding of the pathogenesis of sepsis increases, there is a bigger window for the discovery of therapeutic targets that will yield the desired result. Recently, systems biology is gaining traction as the method of choice for understanding the pathogenesis of diseases and for developing drugs. Its application in sepsis and trauma will be a welcome development. Indeed, some studies have applied systems biology in the mechanistic profiling of sepsis. DNA microarrays and machinelearning algorithms have been used to identify relevant pathways in the pathogenesis of sepsis [145, 146]. In the future, it is expected that the menace of sepsis in intensive care medicine will be effectively curtailed.

\section{Acknowledgements}

This work was supported by funding from the Canadian Institutes of Health Research, the Manitoba Health Research Council and the Children's Hospital Research Institute of Manitoba.

\section{References}

1 Martin GS, Mannino DM, Moss M: The effect of age on the development and outcome of adult sepsis. Crit Care Med 2006;34:15-21.

-2 Martin GS, Mannino DM, Eaton S, Moss M: The epidemiology of sepsis in the United States from 1979 through 2000. N Engl J Med 2003;348:1546-1554.

>3 Gaieski DF, Edwards JM, Kallan MJ, Carr BG: Benchmarking the incidence and mortality of severe sepsis in the United States. Crit Care Med 2013;41:1167-1174.
4 Kaukonen KM, Bailey M, Suzuki S, Pilcher D, Bellomo R: Mortality related to severe sepsis and septic shock among critically ill patients in Australia and New Zealand, 2000-2012. JAMA 2014;311:1308-1316.

5 Kumar G, Kumar N, Taneja A, Kaleekal T, Tarima S, McGinley E, Jimenez E, Mohan A, Khan RA, Whittle J, Jacobs E, Nanchal R: Nationwide trends of severe sepsis in the 21st century (2000-2007). Chest 2011;140:12231231.
6 Stevenson EK, Rubenstein AR, Radin GT, Wiener RS, Walkey AJ: Two decades of mortality trends among patients with severe sepsis: a comparative meta-analysis. Crit Care Med 2014;42:625-631.

7 Dombrovskiy VY, Martin AA, Sunderram J, Paz HL: Facing the challenge: decreasing case fatality rates in severe sepsis despite increasing hospitalizations. Crit Care Med 2005;33: 2555-2562.

-8 Iwashyna TJ: Survivorship will be the defining challenge of critical care in the 21st century. Ann Intern Med 2010;153:204-205.
Management of Sepsis in Critical Care Medicine
J Innate Immun 2016;8:156-170 DOI: $10.1159 / 000442469$ 
-9 Iwashyna TJ, Cooke CR, Wunsch H, Kahn JM: Population burden of long-term survivorship after severe sepsis in older Americans. J Am Geriatr Soc 2012;60:1070-1077.

$\checkmark 10$ Lagu T, Rothberg MB, Shieh MS, Pekow PS, Steingrub JS, Lindenauer PK: Hospitalizations, costs, and outcomes of severe sepsis in the United States 2003 to 2007. Crit Care Med 2012;40:754-761.

11 Thomas L: Germs. N Engl J Med 1972;287: 553-555.

-12 Bone RC, Balk RA, Cerra FB, Dellinger RP, Fein AM, Knaus WA, Schein RM, Sibbald WJ: Definitions for sepsis and organ failure and guidelines for the use of innovative therapies in sepsis. The ACCP/SCCM consensus conference committee. American College of Chest Physicians/Society of Critical Care Medicine. Chest 1992;101:1644-1655.

-13 Levy MM, Fink MP, Marshall JC, Abraham E, Angus D, Cook D, Cohen J, Opal SM, Vincent JL, Ramsay G: 2001 SCCM/ESICM/ACCP/ ATS/SIS International Sepsis Definitions Conference. Crit Care Med 2003;31:1250-1256.

14 Pierrakos C, Vincent JL: Sepsis biomarkers: a review. Crit Care 2010;14:R15.

-15 Povoa P, Almeida E, Moreira P, Fernandes A, Mealha R, Aragao A, Sabino H: C-reactive protein as an indicator of sepsis. Intensive Care Med 1998;24:1052-1056.

-16 Shaoul R, Lahad A, Tamir A, Lanir A, Srugo I: C-reactive protein (CRP) as a predictor for true bacteremia in children. Med Sci Monit 2008; 14:CR255-CR261.

17 Schmit X, Vincent JL: The time course of blood C-reactive protein concentrations in relation to the response to initial antimicrobial therapy in patients with sepsis. Infection 2008;36:213-219.

18 Ranzani OT, Prada LF, Zampieri FG, Battaini LC, Pinaffi JV, Setogute YC, Salluh JI, Povoa P, Forte DN, Azevedo LC, Park M: Failure to reduce C-reactive protein levels more than $25 \%$ in the last 24 hours before intensive care unit discharge predicts higher in-hospital mortality: a cohort study. J Crit Care 2012;27: 525.e529-e515.

19 Uzzan B, Cohen R, Nicolas P, Cucherat M, Perret GY: Procalcitonin as a diagnostic test for sepsis in critically ill adults and after surgery or trauma: a systematic review and metaanalysis. Crit Care Med 2006;34:1996-2003.

20 Snider RH Jr, Nylen ES, Becker KL: Procalcitonin and its component peptides in systemic inflammation: immunochemical characterization. J Investig Med 1997;45:552-560.

-21 Hohn A, Schroeder S, Gehrt A, Bernhardt K, Bein B, Wegscheider K, Hochreiter M: Procalcitonin-guided algorithm to reduce length of antibiotic therapy in patients with severe sepsis and septic shock. BMC Infect Dis 2013; 13:158.

22 Giamarellos-Bourboulis EJ, Tsangaris I, Kanni T, Mouktaroudi M, Pantelidou I, et al: Procalcitonin as an early indicator of outcome in sepsis: a prospective observational study. J Hosp Infect 2011;77:58-63.
23 Riedel S, Melendez JH, An AT, Rosenbaum JE, Zenilman JM: Procalcitonin as a marker for the detection of bacteremia and sepsis in the emergency department. Am J Clin Pathol 2011;135:182-189.

24 Tang BM, Eslick GD, Craig JC, McLean AS: Accuracy of procalcitonin for sepsis diagnosis in critically ill patients: systematic review and meta-analysis. Lancet Infect Dis 2007;7:210217.

25 Mickiewicz B, Vogel HJ, Wong HR, Winston BW: Metabolomics as a novel approach for early diagnosis of pediatric septic shock and its mortality. Am J Respir Crit Care Med 2013; 187:967-976.

26 Kwon OK, Lee W, Kim SJ, Lee YM, Lee JY, Kim JY, Bae JS, Lee S: In-depth proteomics approach of secretome to identify novel biomarker for sepsis in LPS-stimulated endothelial cells. Electrophoresis 2015, Epub ahead of print.

27 Nakada TA, Russell JA, Boyd JH, Thair SA, Walley KR: Identification of a nonsynonymous polymorphism in the SVEP1 gene associated with altered clinical outcomes in septic shock. Crit Care Med 2015;43:101-108.

28 Gibot S, Bene MC, Noel R, Massin F, Guy J, Cravoisy A, Barraud D, De Carvalho Bittencourt M, Quenot JP, Bollaert PE, Faure G, Charles PE: Combination biomarkers to diagnose sepsis in the critically ill patient. Am J Respir Crit Care Med 2012;186:65-71.

29 Sommers MS: The cellular basis of septic shock. Crit Care Nurs Clin North Am 2003; 15:13-25.

30 Brodsky IE, Medzhitov R: Targeting of immune signalling networks by bacterial pathogens. Nat Cell Biol 2009;11:521-526.

-31 Bone RC: The pathogenesis of sepsis. Ann Intern Med 1991;115:457-469.

32 Bone RC: Sir Isaac Newton, sepsis, SIRS, and CARS. Crit Care Med 1996;24:1125-1128.

33 Janeway CA Jr: The immune system evolved to discriminate infectious nonself from noninfectious self. Immunol Today 1992;13:1116.

34 Kawai T, Akira S: The roles of TLRS, RLRS and NLRS in pathogen recognition. Int Immunol 2009;21:317-337.

- 35 Namas R, Zamora R, An G, Doyle J, Dick TE, Jacono FJ, Androulakis IP, Nieman GF, Chang S, Billiar TR, Kellum JA, Angus DC, Vodovotz Y: Sepsis: something old, something new, and a systems view. J Crit Care 2012;27:314

-36 Lu YC, Yeh WC, Ohashi PS: LPS/TLR4 signal transduction pathway. Cytokine 2008;42: 145-151.

37 Dofferhoff AS, Vellenga E, Limburg PC, van Zanten A, Mulder PO, Weits J: Tumour necrosis factor (cachectin) and other cytokines in septic shock: a review of the literature. Neth J Med 1991;39:45-62.

38 Miyoshi T, Yamashita K, Arai T, Yamamoto K, Mizugishi K, Uchiyama T: The role of endothelial interleukin-8/NADPH oxidase 1 axis in sepsis. Immunology 2010;131:331-339.
39 Heller A, Koch T, Schmeck J, van Ackern K: Lipid mediators in inflammatory disorders. Drugs 1998;55:487-496.

40 Ward PA: The harmful role of C5a on innate immunity in sepsis. J Innate Immun 2010;2: 439-445.

41 Gando S, Sawamura A, Hayakawa M: Trauma, shock, and disseminated intravascular coagulation: lessons from the classical literature. Ann Surg 2011;254:10-19.

42 Hotchkiss RS, Coopersmith CM, McDunn JE, Ferguson TA: The sepsis seesaw: tilting toward immunosuppression. Nat Med 2009;15: 496-497.

43 Opal SM, DePalo VA: Anti-inflammatory cytokines. Chest 2000;117:1162-1172.

44 Fiorentino DF, Zlotnik A, Vieira P, Mosmann TR, Howard M, Moore KW, O'Garra A: IL-10 acts on the antigen-presenting cell to inhibit cytokine production by Th1 cells. J Immunol 1991;146:3444-3451.

45 Ninomiya C, Spiegelberg HL: IL-4 and transforming growth factor-beta suppress human immunoglobulin secretion in vitro by surface IgD- B cells. Clin Exp Immunol 1992;89:261268

46 Kehrl JH, Wakefield LM, Roberts AB, Jakowlew S, Alvarez-Mon M, Derynck R, Sporn MB, Fauci AS: Production of transforming growth factor beta by human $\mathrm{T}$ lymphocytes and its potential role in the regulation of $\mathrm{T}$ cell growth. J Exp Med 1986;163:1037-1050.

47 Finder J, Stark WW Jr, Nakayama DK, Geller D, Wasserloos K, Pitt BR, Davies P: TGF-beta regulates production of $\mathrm{NO}$ in pulmonary artery smooth muscle cells by inhibiting expression of NOS. Am J Physiol 1995;268:L862L867.

48 Ocuin LM, Bamboat ZM, Balachandran VP, Cavnar MJ, Obaid H, Plitas G, DeMatteo RP: Neutrophil IL-10 suppresses peritoneal inflammatory monocytes during polymicrobial sepsis. J Leukoc Biol 2011;89:423-432.

49 Weber GF, Chousterman BG, He S, Fenn AM, Nairz M, Anzai A, Brenner T, Uhle F, Iwamoto Y, Robbins CS, Noiret L, Maier SL, Zonnchen T, Rahbari NN, Scholch S, Klotzsche-von Ameln A, Chavakis T, Weitz J, Hofer S, Weigand MA, Nahrendorf M, Weissleder R, Swirski FK: Interleukin-3 amplifies acute inflammation and is a potential therapeutic target in sepsis. Science 2015;347: 1260-1265.

50 An G, Nieman G, Vodovotz Y: Computational and systems biology in trauma and sepsis: current state and future perspectives. Int J Burns Trauma 2012;2:1-10.

51 Paule W, Conte NF: Staphylococcal septicemia; report of a case with hyponatremia and eventual recovery through use of multiple antibiotics and adrenal steroids. AMA Arch Intern Med 1959;103:796-798.

52 Cronin L, Cook DJ, Carlet J, Heyland DK, King D, Lansang MA, Fisher CJ Jr: Corticosteroid treatment for sepsis: a critical appraisal and meta-analysis of the literature. Crit Care Med 1995;23:1430-1439. 
53 Maxime V, Siami S, Annane D: Metabolism modulators in sepsis: the abnormal pituitary response. Crit Care Med 2007;35:S596-S601.

- 54 Tsao CM, Ho ST, Chen A, Wang JJ, Li CY, Tsai SK, Wu CC: Low-dose dexamethasone ameliorates circulatory failure and renal dysfunction in conscious rats with endotoxemia. Shock 2004;21:484-491.

55 Hicks CW, Sweeney DA, Danner RL, Eichacker PQ, Suffredini AF, Feng J, Sun J, Moriyama B, Wesley R, Behrend EN, Solomon SB, Natanson C: Beneficial effects of stress-dose corticosteroid therapy in canines depend on the severity of staphylococcal pneumonia. Intensive Care Med 2012;38:2063-2071.

-56 Annane D, Sebille V, Charpentier C, Bollaert PE, Francois B, Korach JM, Capellier G, Cohen Y, Azoulay E, Troche G, ChaumetRiffaud P, Bellissant E: Effect of treatment with low doses of hydrocortisone and fludrocortisone on mortality in patients with septic shock. JAMA 2002;288:862-871.

- 57 Sprung CL, Annane D, Keh D, Moreno R, Singer M, Freivogel K, Weiss YG, Benbenishty J, Kalenka A, Forst H, Laterre PF, Reinhart K, Cuthbertson BH, Payen D, Briegel J: Hydrocortisone therapy for patients with septic shock. N Engl J Med 2008;358:111-124.

- 58 Boonen E, Vervenne H, Meersseman P, Andrew R, Mortier L, Declercq PE, Vanwijngaerden YM, Spriet I, Wouters PJ, Vander Perre S, Langouche L, Vanhorebeek I, Walker BR, Van den Berghe G: Reduced cortisol metabolism during critical illness. N Engl J Med 2013;368:1477-1488.

-59 Zheng Y, Guo Z, He W, Yang Y, Li Y, Zheng A, Li P, Zhang Y, Ma J, Wen M, Yang M, An H, Ji G, Yu Y: Ephedrine hydrochloride protects mice from LPS challenge by promoting IL-10 secretion and inhibiting proinflammatory cytokines. Int Immunopharmacol 2012; 13:46-53.

-60 Ambade A, Catalano D, Lim A, Mandrekar P: Inhibition of heat shock protein (molecular weight $90 \mathrm{kDa}$ ) attenuates proinflammatory cytokines and prevents lipopolysaccharideinduced liver injury in mice. Hepatology 2012;55:1585-1595.

61 Marshall JC, Foster D, Vincent JL, Cook DJ, Cohen J, Dellinger RP, Opal S, Abraham E, Brett SJ, Smith T, Mehta S, Derzko A, Romaschin A: Diagnostic and prognostic implications of endotoxemia in critical illness: results of the MEDIC study. J Infect Dis 2004; 190:527-534

62 Roger T, Froidevaux C, Le Roy D, Reymond MK, Chanson AL, Mauri D, Burns K, Riederer BM, Akira S, Calandra T: Protection from lethal Gram-negative bacterial sepsis by targeting Toll-like receptor 4. Proc Natl Acad Sci USA 2009; 106:2348-2352.

63 Jung K, Lee JE, Kim HZ, Kim HM, Park BS, Hwang SI, Lee JO, Kim SC, Koh GY: Toll-like receptor 4 decoy, TOY, attenuates Gram-negative bacterial sepsis. PLoS One 2009;4:e7403.

64 Christ WJ, Asano O, Robidoux AL, Perez M, Wang Y, Dubuc GR, Gavin WE, Hawkins LD,
McGuinness PD, Mullarkey MA: E5531, a pure endotoxin antagonist of high potency. Science 1995;268:80-83.

65 Bunnell E, Lynn M, Habet K, Neumann A, Perdomo CA, Friedhoff LT, Rogers SL, Parrillo JE: A lipid A analog, e5531, blocks the endotoxin response in human volunteers with experimental endotoxemia. Crit Care Med 2000;28:2713-2720.

66 Opal SM, Laterre PF, Francois B, LaRosa SP, Angus DC, Mira JP, Wittebole X, Dugernier T, Perrotin D, Tidswell M, Jauregui L, Krell K, Pachl J, Takahashi T, Peckelsen C, Cordasco E, Chang CS, Oeyen S, Aikawa N, Maruyama T, Schein R, Kalil AC, Van Nuffelen M, Lynn M, Rossignol DP, Gogate J, Roberts MB, Wheeler JL, Vincent JL: Effect of eritoran, an antagonist of MD2-TLR4, on mortality in patients with severe sepsis: the ACCESS randomized trial. JAMA 2013;309: 1154-1162.

-67 Cardoso LS, Araujo MI, Goes AM, Pacifico LG, Oliveira RR, Oliveira SC: Polymyxin B as inhibitor of LPS contamination of Schistosoma mansoni recombinant proteins in human cytokine analysis. Microb Cell Fact 2007;6:1.

68 Tani T, Shoji H, Guadagni G, Perego A: Extracorporeal removal of endotoxin: the polymyxin B-immobilized fiber cartridge. Contrib Nephrol 2010;167:35-44.

69 Cruz DN, Perazella MA, Bellomo R, de Cal M, Polanco N, Corradi V, Lentini P, Nalesso F, Ueno T, Ranieri VM, Ronco C: Effectiveness of polymyxin B-immobilized fiber column in sepsis: a systematic review. Crit Care 2007; 11:R47.

70 Cruz DN, Antonelli M, Fumagalli R, Foltran F, Brienza N, Donati A, Malcangi V, Petrini F, Volta G, Bobbio Pallavicini FM, Rottoli F, Giunta F, Ronco C: Early use of polymyxin B hemoperfusion in abdominal septic shock: the EUPHAS randomized controlled trial. JAMA 2009;301:2445-2452.

71 Klein DJ, Foster D, Schorr CA, Kazempour K, Walker PM, Dellinger RP: The Euphrates trial (evaluating the use of polymyxin B hemoperfusion in a randomized controlled trial of adults treated for endotoxemia and septic shock): study protocol for a randomized controlled trial. Trials 2014;15:218.

72 Vincent JL, Rello J, Marshall J, Silva E, Anzueto A, Martin CD, Moreno R, Lipman J, Gomersall C, Sakr Y, Reinhart K: International study of the prevalence and outcomes of infection in intensive care units. JAMA 2009; 302:2323-2329.

73 Levels JH, Marquart JA, Abraham PR, van den Ende AE, Molhuizen HO, van Deventer SJ, Meijers JC: Lipopolysaccharide is transferred from high-density to low-density lipoproteins by lipopolysaccharide-binding protein and phospholipid transfer protein. Infect Immun 2005;73:2321-2326.

74 Shao B, Munford RS, Kitchens R, Varley AW: Hepatic uptake and deacylation of the LPS in blood-borne LPS-lipoprotein complexes. Innate Immun 2012;18:825-833.
75 Vreugdenhil AC, Rousseau CH, Hartung T, Greve JW, van 't Veer C, Buurman WA: Lipopolysaccharide (LPS)-binding protein mediates LPS detoxification by chylomicrons. J Immunol 2003;170:1399-1405.

76 McNutt MC, Kwon HJ, Chen C, Chen JR, Horton JD, Lagace TA: Antagonism of secreted PCSK9 increases low density lipoprotein receptor expression in HEPG2 cells. J Biol Chem 2009;284:10561-10570.

77 Kathiresan S, Voight BF, Purcell S, Musunuru $\mathrm{K}$, Ardissino D, et al: Genome-wide association of early-onset myocardial infarction with single nucleotide polymorphisms and copy number variants. Nat Genet 2009;41:334341.

78 Stein EA, Gipe D, Bergeron J, Gaudet D, Weiss R, Dufour R, Wu R, Pordy R: Effect of a monoclonal antibody to PCSK9, REGN727/ SAR236553, to reduce low-density lipoprotein cholesterol in patients with heterozygous familial hypercholesterolaemia on stable statin dose with or without ezetimibe therapy: a phase 2 randomised controlled trial. Lancet 2012;380:29-36.

79 Walley KR, Thain KR, Russell JA, Reilly MP, Meyer NJ, Ferguson JF, Christie JD, Nakada TA, Fjell CD, Thair SA, Cirstea MS, Boyd JH: PCSK9 is a critical regulator of the innate immune response and septic shock outcome. Sci Transl Med 2014;6:258ra143.

80 Pappas DA, Bathon JM, Hanicq D, Yasothan U, Kirkpatrick P: Golimumab. Nat Rev Drug Discov 2009;8:695-696.

-81 Reinhart K, Menges T, Gardlund B, Harm Zwaveling J, Smithes M, Vincent JL, Tellado JM, Salgado-Remigio A, Zimlichman R, Withington S, Tschaikowsky $\mathrm{K}$, Brase R, Damas P, Kupper H, Kempeni J, Eiselstein J, Kaul M: Randomized, placebo-controlled trial of the anti-tumor necrosis factor antibody fragment afelimomab in hyperinflammatory response during severe sepsis: the RAMSES study. Crit Care Med 2001;29: 765-769.

82 Bernard GR, Francois B, Mira JP, Vincent JL, Dellinger RP, Russell JA, Larosa SP, Laterre PF, Levy MM, Dankner W, Schmitt N, Lindemann J, Wittebole X: Evaluating the efficacy and safety of two doses of the polyclonal antitumor necrosis factor-alpha fragment antibody azd9773 in adult patients with severe sepsis and/or septic shock: randomized, double-blind, placebo-controlled phase IIb study. Crit Care Med 2014;42:504-511.

83 Yang H, Ochani M, Li J, Qiang X, Tanovic M, Harris HE, Susarla SM, Ulloa L, Wang H, DiRaimo R, Czura CJ, Roth J, Warren HS, Fink MP, Fenton MJ, Andersson U, Tracey KJ: Reversing established sepsis with antagonists of endogenous high-mobility group box 1 . Proc Natl Acad Sci USA 2004;101:296-301.

-84 Takahashi N, Vanlaere I, de Rycke R, Cauwels A, Joosten LA, Lubberts E, van den Berg WB, Libert C: IL-17 produced by Paneth cells drives TNF-induced shock. J Exp Med 2008; 205:1755-1761.
Management of Sepsis in Critical Care Medicine
J Innate Immun 2016;8:156-170 DOI: $10.1159 / 000442469$ 
85 Wakabayashi G, Gelfand JA, Burke JF, 97 Thompson RC, Dinarello CA: A specific receptor antagonist for interleukin 1 prevents Escherichia coli-induced shock in rabbits. FASEB J 1991;5:338-343.

86 Cohen J, Opal S, Calandra T: Sepsis studies need new direction. Lancet Infect Dis 2012; 12:503-505.

87 Biswas SK, Lopez-Collazo E: Endotoxin tolerance: new mechanisms, molecules and clinical significance. Trends Immunol 2009;30: 475-487.

88 Astiz M, Saha D, Lustbader D, Lin R, Rackow E: Monocyte response to bacterial toxins, expression of cell surface receptors, and release of anti-inflammatory cytokines during sepsis. J Lab Clin Med 1996;128:594-600.

89 Manjuck J, Saha DC, Astiz M, Eales LJ, Rackow EC: Decreased response to recall antigens is associated with depressed costimulatory receptor expression in septic critically ill patients. J Lab Clin Med 2000 135:153-160.

-90 Zhang X, Morrison DC: Lipopolysaccharide structure-function relationship in activation versus reprogramming of mouse peritoneal macrophages. J Leukoc Biol 1993;54:444450.

-91 Shalova IN, Lim JY, Chittezhath M, Zinkernagel AS, Beasley F, Hernandez-Jimenez E, Toledano V, Cubillos-Zapata C, Rapisarda A, Chen J, Duan K, Yang H, Poidinger M, Melillo G, Nizet V, Arnalich F, Lopez-Collazo E, Biswas SK: Human monocytes undergo functional re-programming during sepsis mediated by hypoxia-inducible factor-1alpha. Immunity 2015;42:484-498.

92 Boomer JS, To K, Chang KC, Takasu O, Osborne DF, Walton AH, Bricker TL, Jarman SD 2nd, Kreisel D, Krupnick AS, Srivastava A, Swanson PE, Green JM, Hotchkiss RS: Immunosuppression in patients who die of sepsis and multiple organ failure. JAMA 2011;306: 2594-2605.

-93 Inoue S, Suzuki K, Komori Y, Morishita Y, Suzuki-Utsunomiya K, Hozumi K, Inokuchi S, Sato T: Persistent inflammation and T cell exhaustion in severe sepsis in the elderly. Crit Care 2014;18:R130.

\$4 Liu ZG, Ni SY, Chen GM, Cai J, Guo ZH, Chang P, Li YS: Histones-mediated lymphocyte apoptosis during sepsis is dependent on p38 phosphorylation and mitochondrial permeability transition. PLoS One 2013;8: e77131.

95 Felmet KA, Hall MW, Clark RS, Jaffe R, Carcillo JA: Prolonged lymphopenia, lymphoid depletion, and hypoprolactinemia in children with nosocomial sepsis and multiple organ failure. J Immunol 2005;174:37653772.

-96 Zhu J, Wang J, Sheng Y, Zou Y, Bo L, Wang F, Lou J, Fan X, Bao R, Wu Y, Chen F, Deng $\mathrm{X}, \mathrm{Li}$ J: Baicalin improves survival in a murine model of polymicrobial sepsis via suppressing inflammatory response and lymphocyte apoptosis. PLoS One 2012;7:e35523.
Walton AH, Muenzer JT, Rasche D, Boomer JS, Sato B, Brownstein BH, Pachot A, Brooks TL, Deych E, Shannon WD, Green JM, Storch GA, Hotchkiss RS: Reactivation of multiple viruses in patients with sepsis. PLoS One 2014;9:e98819.

98 Liang D, Hou Y, Lou X, Chen H: Decoy receptor 3 improves survival in experimental sepsis by suppressing the inflammatory response and lymphocyte apoptosis. PLoS One 2015;10:e131680.

Jiang Q, Li WQ, Aiello FB, Mazzucchelli R, Asefa B, Khaled AR, Durum SK: Cell biology of IL-7, a key lymphotrophin. Cytokine Growth Factor Rev 2005;16:513-533.

100 Mackall CL, Fry TJ, Gress RE: Harnessing the biology of IL-7 for therapeutic application. Nat Rev Immunol 2011;11:330-342.

101 Puel A, Ziegler SF, Buckley RH, Leonard WJ: Defective IL7R expression in $\mathrm{T}(-) \mathrm{B}(+)$ $\mathrm{NK}(+)$ severe combined immunodeficiency. Nat Genet 1998;20:394-397.

102 Unsinger J, Burnham CA, McDonough J, Morre M, Prakash PS, Caldwell CC, Dunne WM Jr, Hotchkiss RS: Interleukin-7 ameliorates immune dysfunction and improves survival in a 2-hit model of fungal sepsis. J Infect Dis 2012;206:606-616.

103 Venet F, Foray AP, Villars-Mechin A, Malcus C, Poitevin-Later F, Lepape A, Monneret G: Il-7 restores lymphocyte functions in septic patients. J Immunol 2012;189:50735081.

104 Kasten KR, Prakash PS, Unsinger J, Goetzman HS, England LG, Cave CM, Seitz AP, Mazuski CN, Zhou TT, Morre M, Hotchkiss RS, Hildeman DA, Caldwell CC: Interleukin-7 (IL-7) treatment accelerates neutrophil recruitment through gamma delta T-cell IL-17 production in a murine model of sepsis. Infect Immun 2010;78:47144722.

105 Ahn SS, Jeon BY, Park SJ, Choi DH, Ku SH, Cho SN, Sung YC: Nonlytic Fc-fused IL-7 synergizes with Mtb32 DNA vaccine to enhance antigen-specific $\mathrm{T}$ cell responses in a therapeutic model of tuberculosis. Vaccine 2013;31:2884-2890.

106 Flohe SB, Agrawal H, Flohe S, Rani M, Bangen JM, Schade FU: Diversity of interferon gamma and granulocyte-macrophage colony-stimulating factor in restoring immune dysfunction of dendritic cells and macrophages during polymicrobial sepsis. Mol Med 2008; 14:247-256.

107 Meisel C, Schefold JC, Pschowski R, Baumann T, Hetzger K, Gregor J, WeberCarstens S, Hasper D, Keh D, Zuckermann H, Reinke P, Volk HD: Granulocyte-macrophage colony-stimulating factor to reverse sepsis-associated immunosuppression: a double-blind, randomized, placebo-controlled multicenter trial. Am J Respir Crit Care Med 2009;180:640-648.

108 Pardoll DM: The blockade of immune checkpoints in cancer immunotherapy. Nat Rev Cancer 2012;12:252-264.
09 Brahmer JR, Tykodi SS, Chow LQ, Hwu WJ, Topalian SL, Hwu P, Drake CG, Camacho LH, Kauh J, Odunsi K, Pitot HC, Hamid O, Bhatia S, Martins R, Eaton K, Chen S, Salay TM, Alaparthy S, Grosso JF, Korman AJ, Parker SM, Agrawal S, Goldberg SM, Pardoll DM, Gupta A, Wigginton JM: Safety and activity of anti-PD-L1 antibody in patients with advanced cancer. N Engl J Med 2012; 366:2455-2465.

110 Hotchkiss RS, Moldawer LL: Parallels between cancer and infectious disease. N Engl J Med 2014;371:380-383.

111 Brahmamdam P, Inoue S, Unsinger J, Chang KC, McDunn JE, Hotchkiss RS: Delayed administration of anti-PD-1 antibody reverses immune dysfunction and improves survival during sepsis. J Leukoc Biol 2010;88:233-240.

112 Chang KC, Burnham CA, Compton SM, Rasche DP, Mazuski RJ, McDonough JS, Unsinger J, Korman AJ, Green JM, Hotchkiss RS: Blockade of the negative co-stimulatory molecules PD-1 and CTLA-4 improves survival in primary and secondary fungal sepsis. Crit Care 2013;17:R85.

113 Sakaguchi S, Sakaguchi N, Asano M, Itoh M, Toda M: Immunologic self-tolerance maintained by activated $\mathrm{T}$ cells expressing IL-2 receptor alpha-chains (CD25). Breakdown of a single mechanism of self-tolerance causes various autoimmune diseases. J Immunol 1995;155:1151-1164.

114 Setoguchi R, Hori S, Takahashi T, Sakaguchi $S$ : Homeostatic maintenance of natural Foxp3(+) CD25(+) CD4(+) regulatory $\mathrm{T}$ cells by interleukin (IL)-2 and induction of autoimmune disease by IL-2 neutralization. J Exp Med 2005;201:723-735.

115 Roncarolo MG, Battaglia M: Regulatory Tcell immunotherapy for tolerance to self antigens and alloantigens in humans. Nat Rev Immunol 2007;7:585-598.

116 Monneret G, Debard AL, Venet F, Bohe J, Hequet $\mathrm{O}$, Bienvenu J, Lepape A: Marked elevation of human circulating CD4+CD25+ regulatory $\mathrm{T}$ cells in sepsis-induced immunoparalysis. Crit Care Med 2003;31:20682071.

117 Wisnoski N, Chung CS, Chen Y, Huang X, Ayala A: The contribution of CD4+ CD25+ T-regulatory-cells to immune suppression in sepsis. Shock 2007;27:251-257.

118 Hein F, Massin F, Cravoisy-Popovic A, Barraud D, Levy B, Bollaert PE, Gibot S: The relationship between CD4+CD25+CD127regulatory $\mathrm{T}$ cells and inflammatory response and outcome during shock states. Crit Care 2010;14:R19.

119 Scumpia PO, Delano MJ, Kelly KM, O'Malley KA, Efron PA, McAuliffe PF, Brusko T, Ungaro R, Barker T, Wynn JL, Atkinson MA, Reeves WH, Salzler MJ, Moldawer LL: Increased natural CD4+ $\mathrm{CD} 25+$ regulatory $\mathrm{T}$ cells and their suppressor activity do not contribute to mortality in murine polymicrobial sepsis. J Immunol 2006;177:7943-7949. 
120 Carrigan SO, Yang YJ, Issekutz T, Forward N, Hoskin D, Johnston B, Lin TJ: Depletion of natural $\mathrm{CD} 4+\mathrm{CD} 25+\mathrm{T}$ regulatory cells with anti-CD25 antibody does not change the course of Pseudomonas aeruginosa-induced acute lung infection in mice. Immunobiology 2009;214:211-222.

-121 Venet F, Chung CS, Kherouf H, Geeraert A, Malcus C, Poitevin F, Bohe J, Lepape A, Ayala A, Monneret G: Increased circulating regulatory T cells $(\mathrm{CD} 4(+) \mathrm{CD} 25(+) \mathrm{CD} 127(-))$ contribute to lymphocyte anergy in septic shock patients. Intensive Care Med 2009;35: 678-686.

122 Hiraki S, Ono S, Tsujimoto H, Kinoshita M, Takahata R, Miyazaki H, Saitoh D, Hase K: Neutralization of interleukin-10 or transforming growth factor- $\beta$ decreases the percentages of CD4(+)CD25(+)Foxp3(+) regulatory $\mathrm{T}$ cells in septic mice, thereby leading to an improved survival. Surgery 2012;151: 313-322.

-123 Heuer JG, Zhang T, Zhao J, Ding C, Cramer M, Justen KL, Vonderfecht SL, Na S: Adoptive transfer of in vitro-stimulated $\mathrm{CD} 4+\mathrm{CD} 25+$ regulatory $\mathrm{T}$ cells increases bacterial clearance and improves survival in polymicrobial sepsis. J Immunol 2005; 174 : 7141-7146.

124 Cambos M, Belanger B, Jacques A, Roulet A, Scorza T: Natural regulatory (CD4+ $\mathrm{CD} 25+$ Foxp+) $\mathrm{T}$ cells control the production of pro-inflammatory cytokines during Plasmodium chabaudi adami infection and do not contribute to immune evasion. Int J Parasitol 2008;38:229-238.

125 Okeke EB, Okwor I, Mou Z, Jia P, Uzonna JE: CD4+CD25+ regulatory T cells attenuate lipopolysaccharide-induced systemic inflammatory responses and promotes survival in murine Escherichia coli infection. Shock 2013;40:65-73.

126 Okeke EB, Okwor I, Uzonna JE: Regulatory $\mathrm{T}$ cells restrain CD4+ $\mathrm{T}$ cells from causing unregulated immune activation and hypersensitivity to lipopolysaccharide challenge. J Immunol 2014;193:655-662.

-127 Xiao F, Ma L, Zhao M, Huang G, Mirenda V, Dorling A, Lechler R, Lombardi G: Ex vivo expanded human regulatory $\mathrm{T}$ cells delay islet allograft rejection via inhibiting islet-derived monocyte chemoattractant protein-1 production in $\mathrm{CD} 34+$ stem cells-reconstituted NOD-scid IL2rynull mice. PLoS One 2014;9:e90387.

-128 Nguyen VH, Shashidhar S, Chang DS, Ho L, Kambham N, Bachmann M, Brown JM, Negrin RS: The impact of regulatory $\mathrm{T}$ cells on T-cell immunity following hematopoietic cell transplantation. Blood 2008;111:945-953.

129 Di Ianni M, Falzetti F, Carotti A, Terenzi A, Castellino F, Bonifacio E, Del Papa B, Zei T, Ostini RI, Cecchini D, Aloisi T, Perruccio K, Ruggeri L, Balucani C, Pierini A, Sportoletti P, Aristei C, Falini B, Reisner Y, Velardi A, Aversa F, Martelli MF: Tregs prevent GVHD and promote immune reconstitution in
HLA-haploidentical transplantation. Blood 2011;117:3921-3928.

130 Brunstein CG, Miller JS, Cao Q, McKenna $\mathrm{DH}$, Hippen KL, Curtsinger J, Defor T, Levine BL, June CH, Rubinstein P, McGlave PB, Blazar BR, Wagner JE: Infusion of ex vivo expanded $\mathrm{T}$ regulatory cells in adults transplanted with umbilical cord blood: safety profile and detection kinetics. Blood 2011;117:1061-1070.

131 Cantley LC: The phosphoinositide 3-kinase pathway. Sci 2002;296:1655-1657.

132 Engelman JA, Luo J, Cantley LC: The evolution of phosphatidylinositol 3-kinases as regulators of growth and metabolism. Nat Rev Genet 2006;7:606-619.

133 Whitman M, Downes CP, Keeler M, Keller T, Cantley L: Type I phosphatidylinositol kinase makes a novel inositol phospholipid, phosphatidylinositol-3-phosphate. Nature 1988;332:644-646.

134 Wrann CD, Tabriz NA, Barkhausen T, Klos A, van Griensven M, Pape HC, Kendoff DO, Guo R, Ward PA, Krettek C, Riedemann NC: The phosphatidylinositol 3-kinase signaling pathway exerts protective effects during sepsis by controlling C5a-mediated activation of innate immune functions. J Immunol 2007;178:5940-5948.

135 Jiang S, Zhu W, Li C, Zhang X, Lu T, Ding Z, Cao K, Liu L: $\alpha$-Lipoic acid attenuates LPSinduced cardiac dysfunction through a PI3K/Akt-dependent mechanism. Int Immunopharmacol 2013;16:100-107.

136 Zhang WJ, Wei H, Hagen T, Frei B: $\alpha$-Lipoic acid attenuates LPS-induced inflammatory responses by activating the phosphoinositide 3-kinase/Akt signaling pathway. Proc Natl Acad Sci USA 2007;104:4077-4082.

137 Ong E, Gao XP, Predescu D, Broman M, Malik AB: Role of phosphatidylinositol 3-kinase- $\gamma$ in mediating lung neutrophil sequestration and vascular injury induced by E. coli sepsis. Am j Physiol Lung Cell Mol Physiol 2005;289:L1094-L1103.

138 Martin EL, Souza DG, Fagundes CT, Amaral FA, Assenzio B, Puntorieri V, Del Sorbo L, Fanelli V, Bosco M, Delsedime L, Pinho JF, Lemos VS, Souto FO, Alves-Filho JC, Cunha FQ, Slutsky AS, Ruckle T, Hirsch E, Teixeira MM, Ranieri VM: Phosphoinositide-3 kinase gamma activity contributes to sepsis and organ damage by altering neutrophil recruitment. Am J Respir Crit Care Med 2010; 182:762-773.

139 Patton DT, Garden OA, Pearce WP, Clough LE, Monk CR, Leung E, Rowan WC, Sancho S, Walker LS, Vanhaesebroeck B, Okkenhaug K: Cutting edge: the phosphoinositide 3-kinase p110 delta is critical for the function of CD4+CD25+Foxp3+ regulatory $\mathrm{T}$ cells. J Immunol 2006;177:6598-6602.

140 Marshall JC: The staging of sepsis: understanding heterogeneity in treatment efficacy. Crit Care 2005;9:626-628.

141 Iskander KN, Osuchowski MF, Stearns-Kurosawa DJ, Kurosawa S, Stepien D, Valen- tine C, Remick DG: Sepsis: multiple abnormalities, heterogeneous responses, and evolving understanding. Physiol Rev 2013; 93:1247-1288.

142 Dyson A, Singer M: Animal models of sepsis: why does preclinical efficacy fail to translate to the clinical setting? Crit Care Med 2009; 37:S30-S37.

143 Seok J, Warren HS, Cuenca AG, Mindrinos MN, Baker HV, et al: Genomic responses in mouse models poorly mimic human inflammatory diseases. Proc Natl Acad Sci USA 2013;110:3507-3512.

144 Barkhausen T, Tschernig T, Rosenstiel P, van Griensven M, Vonberg RP, Dorsch M, Mueller-Heine A, Chalaris A, Scheller J, Rose-John S, Seegert D, Krettek C, Waetzig GH: Selective blockade of interleukin- 6 trans-signaling improves survival in a murine polymicrobial sepsis model. Crit Care Med 2011;39:1407-1413.

145 Xiao W, Mindrinos MN, Seok J, Cuschieri J, Cuenca AG, et al: A genomic storm in critically injured humans. J Exp Med 2011;208: 2581-2590.

146 Cohen MJ, Grossman AD, Morabito D, Knudson MM, Butte AJ, Manley GT: Identification of complex metabolic states in critically injured patients using bioinformatic cluster analysis. Crit Care 2010;14:R10.

147 Calandra T, Echtenacher B, Roy DL, Pugin J, Metz CN, Hultner L, Heumann D, Mannel D, Bucala R, Glauser MP: Protection from septic shock by neutralization of macrophage migration inhibitory factor. Nat Med 2000;6:164-170.

148 Czermak BJ, Sarma V, Pierson CL, Warner RL, Huber-Lang M, Bless NM, Schmal H, Friedl HP, Ward PA: Protective effects of C5a blockade in sepsis. Nat Med 1999;5: 788-792.

149 Puneet P, Yap CT, Wong L, Lam Y, Koh DR, Moochhala S, Pfeilschifter J, Huwiler A, Melendez AJ: SphK1 regulates proinflammatory responses associated with endotoxin and polymicrobial sepsis. Sci 2010;328:1290-1294.

150 Pan SL, Guh JH, Peng CY, Chang YL, Cheng FC, Chang JH, Kuo SC, Lee FY, Teng CM: A potential role of $\mathrm{YC}-1$ on the inhibition of cytokine release in peripheral blood mononuclear leukocytes and endotoxemic mouse models. Thrombosis and Haemostasis 2005; 93:940-948.

151 Takano K, Yamamoto S, Tomita K, Takashina M, Yokoo H, Matsuda N, Takano Y, Hattori Y: Successful treatment of acute lung injury with pitavastatin in septic mice: potential role of glucocorticoid receptor expression in alveolar macrophages. J Pharmacol Exp Ther 2011;336:381-390.

152 Yang W, Yamada M, Tamura Y, Chang K, Mao J, Zou L, Feng Y, Kida K, ScherrerCrosbie M, Chao W, Ichinose F, Yu YM, Fischman AJ, Tompkins RG, Yao S, Kaneki M: Farnesyltransferase inhibitor, FTI-277, reduces mortality of septic mice along with improved bacterial clearance. J Pharmacol Exp Ther 2011;339:832-841. 
153 Chuang KI, Leung B, Hsu N, Harris HW: Heparin protects against septic mortality via apoE-antagonism. Am J Surg 2011;202:325335.

154 Becerra A, Echeverria C, Varela D, Sarmiento D, Armisen R, Nunez-Villena F, Montecinos M, Simon F: Transient receptor potential melastatin 4 inhibition prevents lipopolysaccharide-induced endothelial cell death. Cardiovasc Res 2011;91:677-684.

155 Park JH, Hwang IC, Ha N, Lee S, Kim JM, Lee SS, Yu H, Lim IT, You JA, Kim DH: Effects of the anti-sepsis drug, (S)-1-(alphanaphthylmethyl)-6,7-dihydroxy-1,2,3,4-tetrahydroisoquinoline (CKD-712), on mortality, inflammation, and organ injuries in rodent sepsis models. Arch Pharmacol Res 2011;34:485-494.

156 Chen GY, Chen X, King S, Cavassani KA, Cheng J, Zheng X, Cao H, Yu H, Qu J, Fang
D, Wu W, Bai XF, Liu JQ, Woodiga SA, Chen C, Sun L, Hogaboam CM, Kunkel SL, Zheng P, Liu Y: Amelioration of sepsis by inhibiting sialidase-mediated disruption of the CD24-SiglecG interaction. Nat Biotechnol 2011;29:428-435.

157 Cohen TS, Bucki R, Byfield FJ, Ciccarelli NJ, Rosenberg B, DiNubile MJ, Janmey PA, Margulies SS: Therapeutic potential of plasma gelsolin administration in a rat model of sepsis. Cytokine 2011;54:235-238.

158 Igonin AA, Protsenko DN, Galstyan GM, Vlasenko AV, Khachatryan NN, Nekhaev IV, Shlyapnikov SA, Lazareva NB, Herscu P: $\mathrm{C} 1$-esterase inhibitor infusion increases survival rates for patients with sepsis. Crit Care Med 2012;40:770-777.

159 Cadirci E, Halici Z, Odabasoglu F, Albayrak A, Karakus E, Unal D, Atalay F, Ferah I, Unal B: Sildenafil treatment attenuates lung and kidney injury due to overproduction of oxidant activity in a rat model of sepsis: a biochemical and histopathological study. Clin Exp Immunol 2011;166:374-384.

60 Kumpers P, Gueler F, David S, Slyke PV, Dumont DJ, Park JK, Bockmeyer CL, Parikh SM, Pavenstadt H, Haller H, Shushakova N: The synthetic tie2 agonist peptide vasculotide protects against vascular leakage and reduces mortality in murine abdominal sepsis. Crit Care 2011;15:R261.

161 Xu Y, Jiang WL, Zhang SP, Zhu HB, Hou J: Protocatechuic aldehyde protects against experimental sepsis in vitro and in vivo. Basic Clin Pharmacol Toxicol 2012;110:384-389.

162 Gao JP, Huang M, Li N, Wang PF, Chen HL, $\mathrm{Xu}$ QP: Efficacy of a novel endotoxin adsorber polyvinylidene fluoride fiber immobilized with (L)-serine ligand on septic pigs. J Zhejiang Univ Sci B 2011;12:264-272. 